\title{
- $\quad$ OP-0003 - A new component of skeletal muscle secretome on beta cells and prevent TNF-a and cytomix effect on beta-cells
}

Karim Bouzakri, Julien Cherfan, Harzo Hamdard, Carole Mura, Claude Peronet, and Michel Pinget. UMR DIATHEC, EA 7294, Centre Européen d'Etude du Diabète, Université de Strasbourg (UdS), Boulevard René Leriche 67200 Strasbourg, France

\section{Background and aim}

Inter-organ crosstalk including possible communication between skeletal muscle and beta cells is an important component of normal physiology that may contribute towards the pathophysiology of type 2 diabetes. Indeed, skeletal muscle cells secrete different sets of soluble proteins (myokines) which could act positively or negatively (in health and disease respectively) on the function of distant tissues including pancreatic islets. We have observed that conditioned medium from skeletal muscle of healthy individuals has positive effects on beta cell function. Myokine X, was identified as a myokine regulated by muscle fiber type. The major aim of this study was to explore the impact of Myokine $\mathrm{X}$ on primary sorted beta cells under control conditions and after exposure to TNF- $\alpha$ or insulin resistance condition medium from skeletal muscle cells.

\section{Material and methods}

All studies were performed using sorted rat primary beta cells and human islets exposed to Myokine X for 24h. Glucose-stimulated insulin secretion (GSIS) was measured by radioimmunoassay after $1 \mathrm{~h}$ at 2.8 $\mathrm{mmol} / \mathrm{l}$ (basal) and $1 \mathrm{~h}$ at $16.7 \mathrm{mmol} / \mathrm{l}$ (stimulated) glucose. Cell death and proliferation were measured by TUNEL assay and BrdU incorporation respectively. To study the potential beneficial/protective effects of myokine $X$, beta cells were exposed to decorin for $24 \mathrm{~h}$ alone or with addition $20 \mathrm{ng} / \mathrm{ml}$ TNF- $\alpha$ alone or condition medium from insulin resistance soleus skeletal muscle cells (S-SKMC-IR-CM). Data are mean \pm SE for 5-8 independent experiments.

\section{Results :}

Myokine $\mathrm{X}$ treatment increases cell survival and has no effect on proliferation
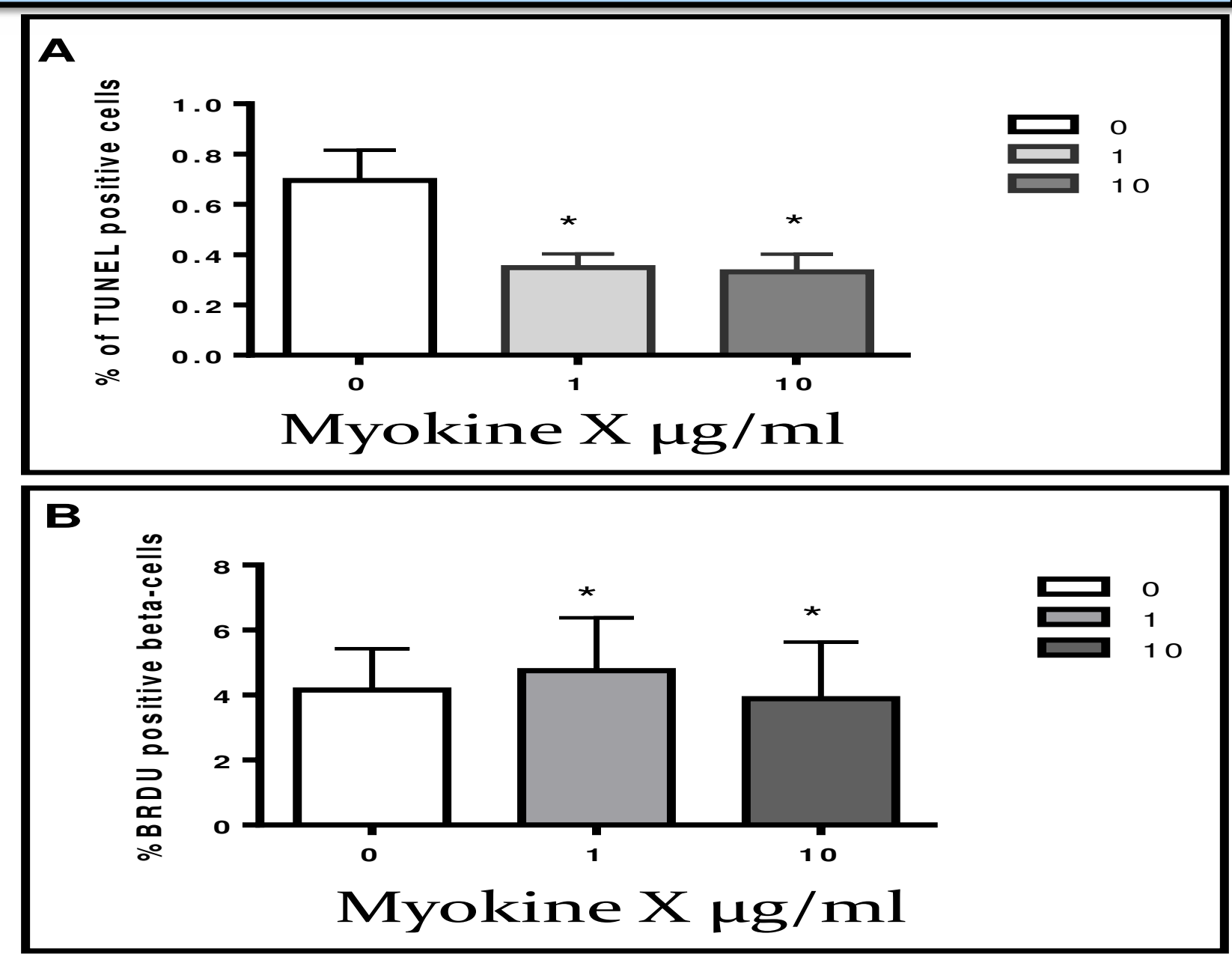

Myokine $X$ decreases rat beta-cells apoptosis without affecting proliferation. Rat sorted beta-cells were cultured with different concentrations of myokine $x(0 ; 1 ; 10 \mu \mathrm{g} / \mathrm{ml})$. A. Rat beta-cells death measured by TUNEL assay. Cell death is expressed as TUNELpositive beta-cells normalized to the Control $(n=6) .{ }^{*} p<0.05$ vs control. B. BRDUpositive rat beta-cells. Proliferation was measured by BRDU incorporation over $24 \mathrm{~h}$ $(n=6)$.

\section{Results: Myokine X impact on GSIS}

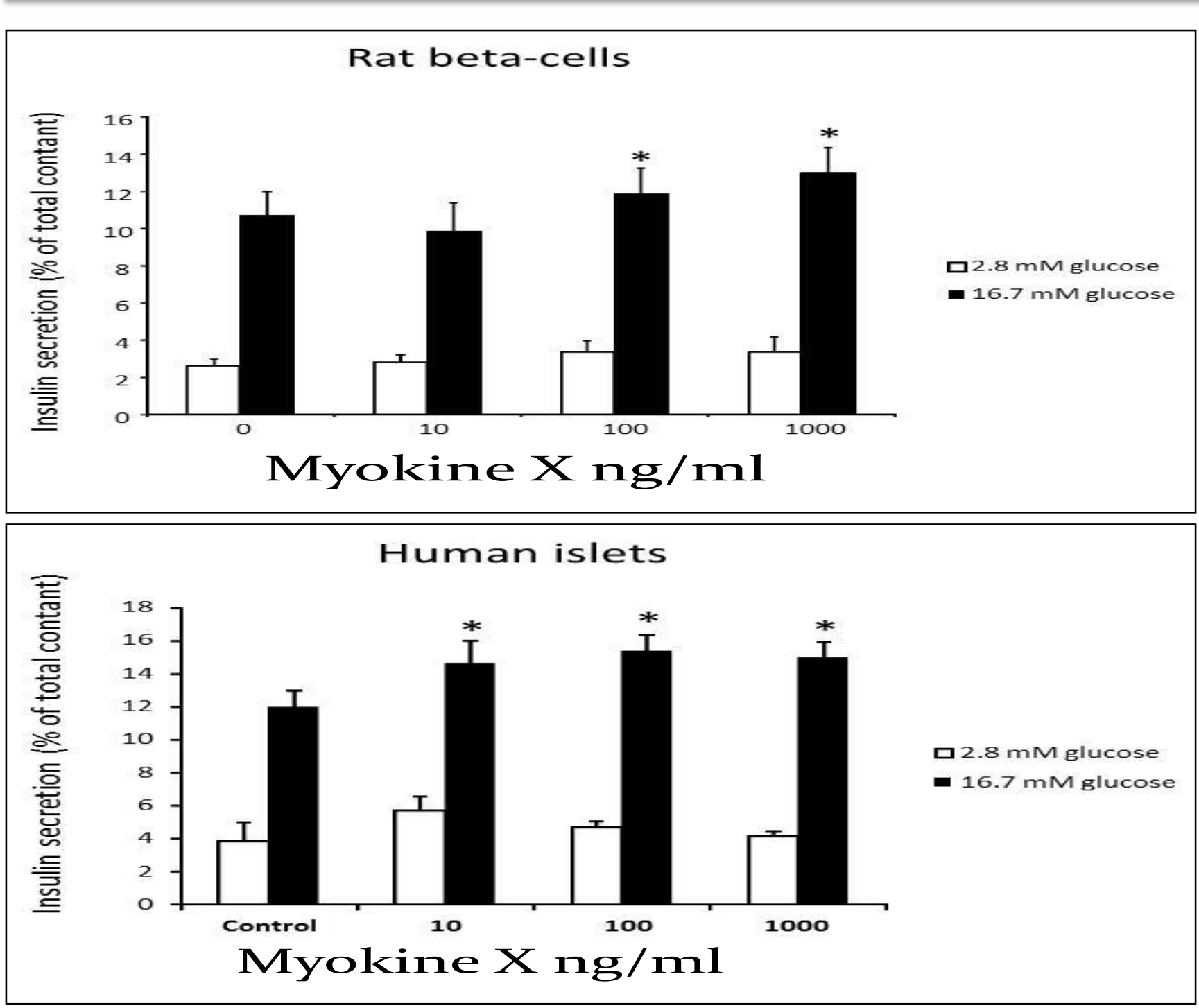

Myokine $X$ treatment increases the glucose-stimulated insulin secretion in rat primary beta-cells and human islets. Representation of insulin secretion (expressed as percentage of cell content/h). Rat primary beta-cells or were cultured for $24 \mathrm{~h}$ with different concentrations of myokine X (0; 10; 100; $1000 \mathrm{ng} / \mathrm{ml})$ and then incubated for $2 \mathrm{~h}$ at $2.8 \mathrm{mM}$ glucose (depletion), before to undergo an incubation for $1 \mathrm{~h}$ at $2.8 \mathrm{mM}$ glucose (open bars) followed by $1 \mathrm{~h}$ at $16.7 \mathrm{mM}$ glucose (closed bars); $(n=5) ;{ }^{*} p<0.05$ vs control.
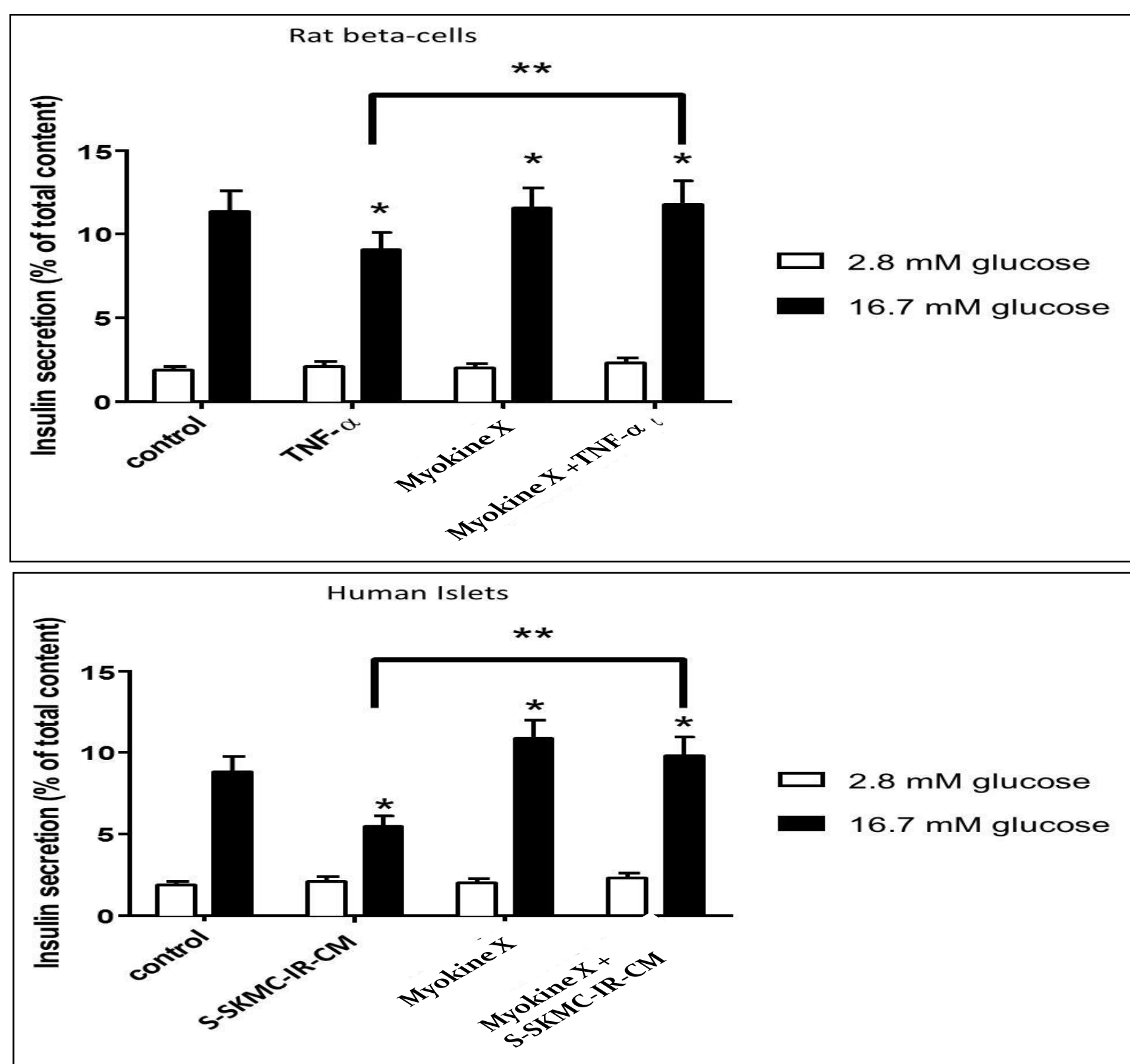

Myokine $X$ treatment prevents the effect of TNF- $\alpha$ and IR-CM impact on glucosestimulated insulin secretion. ${ }^{*} p<0.05$ vs control; ${ }^{* *} p<0.05$ vs. TNF- $\alpha$ alone or S-SKMC-IRCM.

\section{Conclusion}

We demonstrate for the first time that Myokine $X$ has a positive effect on beta cells and human islets, increasing glucose-stimulated insulin secretion and decreasing cell death in the basal state. Moreover, myokine $\mathrm{X}$ protects beta cells and human isles from the adverse effects of TNF- $\alpha$ and S-SKMC-IR-CM, indicating the potential for a specific impact of myokine $X$ on cytokine signaling pathways in beta cells. 